FACTA UNIVERSITATIS

Series: Physical Education and Sport, Vol. 16, No 3, 2018, pp. 621 - 630

https://doi.org/10.22190/FUPES171020056M

Research article

\title{
CAUSES OF NEGATIVE ATTITUDES OF YOUNGER ELEMENTARY SCHOOL STUDENTS TOWARDS CAMPINGS
}

\author{
UDC 796.37.062 \\ 918.4:795.5
}

\author{
Vladimir Miletić ${ }^{1}$, Željko Rajković ${ }^{1}$, Dragan Branković ${ }^{2}$ \\ ${ }^{1}$ Faculty of Sport and Phyisical Education, University of Belgrade, Belgrade, Serbia \\ ${ }^{2}$ Teacher Education Faculty, University of Belgrade, Belgrade, Serbia
}

\begin{abstract}
The organization of compulsory camping activities for elementary and secondary school students was given as a possibility in the educational system of the Republic of Serbia. The precondition for the implementation of this plan with the regulated legislation assumes positive attitudes of both parents and students. Because of their nature, attitudes affect human mental functions. The sample in this study consisted of 252 students of the third and fourth grade, five classes per two elementary schools from Belgrade. A survey was used as an instrument of research, with the main goal of discovering the number of students with a negative attitude towards camping, with explained motives. The results showed that $15.07 \%$ of the respondents would not like to go camping. Some think that they are not mature enough, they do not like the mentioned activity, and they think that their camping would be boring, while some might be bothered by insects. The most frequent projected fears of possible lodging at the campsite are fears directed towards wild animals, bugs, spiders, snakes, darkness, sudden sounds, loss, and unknown people. All the aforementioned fears, regardless of their type, are united by the fear of the unknown, and as a form of solution it is recommended to confront these "inconveniences" and fears whereby this process achieves gradual neutralization and their disappearance. The conclusion is that all these fears could be eradicated by getting to know the students with details about the organization of camping and the location of the camp.
\end{abstract}

Key words: teaching, fears, back to nature

Received October 20, 2017 / Accepted December 13, 2018

Corresponding author: Vladimir Miletić

University of Belgrade, Faculty of Sport and Physical Education, Blagoja Parovića 156, 11000 Belgrade, Serbia Phone: +381 $113531000 •$ E-mail: vladaprof@gmail.com 


\section{INTRODUCTION}

Positive effects of staying in nature are reflected through health-sanitary, psycho-social, sport-recreational and pedagogic-educational importance (Miletić, 2011; Grujić at all, 2017). Research that confirmed the positive effects of totally passive staying in a wood on the human immunity could be mentioned as a best example (Li, 2010). Psycho-social importance mostly could be explained through the adaptation of a human to conform to absence terms, where people return to primary motives and turn to each other (Miletić, Rajković, \& Vidaković, 2016). Sport-recreational importance of staying in nature just emphasizes the health aspect during activities and through relieving and faster merging with nature (Miletić, 2016a; 2016b). The close connection between different contents in nature creates direct contact between summer camps, military and police classes, some areas of medicine, sport, and education (Miletić, 2011).

The attitude represents a neutral and mental readiness formed on the basis of experience that directs and dynamically influences the response of an individual to the objects and situations he is in contact with. Attitudes include three components: a cognitive, emotional, and conative. The cognitive component includes the perceptions and knowledge of objects in which there is an attitude. This knowledge can be very narrow, and it can be a knowledge system. An emotional component means that attitudes always include feelings (pleasures or discomfort) related to the object on which the attitude is formed. The connotation is that there is always a tendency to take action in relation to the object in which the attitude is formed. Because of their nature, attitudes affect human mental functions: perception, learning, memory, emotions, ratings, judgments and opinions (Murchison, 1935).

The school system of the Republic of Serbia recognizes the possibility of organizing obligatory classes through the form of summer camps, for students in elementary and high schools, as extracurricular learning activity, instead of three classes of physical education weekly (Višnjić, Jovanović, \& Miletić, 2004). Serbia is abundant in favorable places for the organization of summer camps, which have not been used sufficiently (Miletić, Rajković \& Mitrović). Some schools perform certain forms of outdoor activities such as cross, field trips, schools in nature, etc. (Farkaš, 2005; Nikolić, 2004).

The precondition for the implementation of the mentioned plan, along with the regulated legislation, presupposes positive attitudes of the parents, as well as of the students themselves (the participants in teaching). The recorded attitudes of parents in the previous research are positive to a great extent (Martinović, Branković, \& Pelemiš, 2013).

In the field of social medicine, a lot of attention is paid to developing and evaluating the attitudes of children towards outdoor activities (Beyer et al., 2015). In this article, students' attitudes are investigated regarding staying in a summer camp, even more because positive attitudes were already recorded from students of Physical education (Dabović, Dobrijević, Miletić, Višnjić, \& Miletić, 2009) and students of the CriminalPolice Academy (Vučković \& Dopsaj, 2011). The majority of studies pointed to a change of attitudes regarding physical education, where older students have less positive attitudes compared to younger ones (Lazarević, Orlić, Lazarević, \& Radisavljević-Janić, 2015). In the research on the mentioned attitudes of younger students, positive attitudes are expected in a large percent. Some studies recognized the negative environmental events that could influence an individual's environmental beliefs (Ewert, Place, \& Sibthorp, 2005). This article pays special attention to students that have a negative attitude regarding summer camp, and will try to give solutions for changing their attitudes, and to enable the realization of outdoor activities in summer camps for the maximum amount of children in Serbia. 
The subject of this research are the reasons for the negative attitudes of younger elementary school students towards the summer camp.

The goals of this research were to determine the cause and fears for negative attitudes of younger elementary school students regarding summer camp, and to define the influence of earlier experience of staying in nature on liberation from existing fears.

\section{METHODS}

In this research, the method of experimental investigation was used, with a special survey questionnaire as an instrument, with a theoretical analysis of literature, causal methods systematized by professional experience, with applying a logical, inductive, and deductive way of conclusion.

The sample in this research were 252 third and fourth grade students, more precisely 5 classes from the "Oslobodioci Beograda" elementary school and 5 classes from the "Borisav Pekić" elementary school from Belgrade.

A survey questionnaire was used as an instrument in this research. The first part of the questionnaire was intended for general information, while next one was used to collect data about the way the students spend leisure time. In one part of the survey the students have displayed negative attitudes towards staying at a camp, and in the last section they provided information about their desires about potential camping (Bondžić, 2012).

In this article, the data about students' negative attitudes regarding camping will be processed.

Statistical analysis was performed using the free statistical software for data processing, "R" (R-project, 2017). During processing, each question was a random variable. All variables were categorical and nominal. The data are presented in tables, expressed as numbers and percentages.

\section{RESULTS}

In earlier studies (Hollender, 1977) regarding motives that influence the decision towards camping, 7 scales were formed as follows (1) Primitive Life Style (2) Escape from Routine Responsibilities, (3) Security of the Campground, (4) Entertainment, (5) Aesthetic Outdoor Experience), (6) Escape from Urban Stress, (7) Escape from the Familiar.

The results of the analysis obtained by surveying students are very positive. $85 \%$ of the surveyed students indicated that they would like to go on a camping trip, while only $15 \%$ said the opposite (Table 1).

Table 1 Students attitudes regarding staying in summer camp (Bondžić, 2012)

\begin{tabular}{ccc}
\hline & Numbers of students & $\begin{array}{c}\% \text { of } \\
\text { students }\end{array}$ \\
\hline & 214 & 84.93 \\
Overall & 38 & 15.07 \\
\hline
\end{tabular}


Although in this article, in the case of only about 38 students, $15.07 \%$ of the total population of students who attend the third and fourth grade in Serbia represents a much larger and more significant number. This article attempts to discover the reasons for negative attitudes of children towards summer camp, in order to eliminate and ignore identified causes, and to enable basic terms for their return to nature.

Table 2 Reasons because of which students do not want to go to summer camp (Bondžić, 2012)

\begin{tabular}{lccc}
\hline & Numbers of students & $\begin{array}{c}\text { \% from overall } \\
\text { number of students }\end{array}$ & $\begin{array}{c}\text { \% of students who would } \\
\text { not go on camping }\end{array}$ \\
\hline Bugs & 4 & 1.59 & 10.53 \\
Insects & 4 & 1.59 & 10.53 \\
Bored & 8 & 3.17 & 21.05 \\
Don't like & 8 & 3.17 & 21.05 \\
Age (too young) & 10 & 3.96 & 26.31 \\
Don't know & 4 & 1.59 & 1.53 \\
\hline
\end{tabular}

Four students, or $1.59 \%$, mentioned bugs as the reason not to go camping, the same number of them, or $1.59 \%$, mentioned the insects, 8 of them, or $3.17 \%$ said that they will be bored, the same number said that they do not like camping, while 10 of them, or $3.96 \%$ considered that their age is not appropriate for such a type of activity, while 4 students had no explanation for their attitude (Table 2).

From the above values collected on a small part of the sample (which represents 38 students or $15.07 \%$ of the total sample), we see that there is no dominant reason that would significantly affect the perspective and implementation of camping as an outdoor activity.

Table 3 Students fears regarding staying in a summer camp (Bondžić, 2012)

\begin{tabular}{lrc}
\hline & Students & \% from overall number of students \\
\hline Without fears & 96 & 38.09 \\
With fears & 156 & 61.91 \\
Overall & 252 & 100 \\
\hline & Fears & \% from overall fears \\
\hline Bugs and spiders & 46 & 29.11 \\
Wild animals & 72 & 45.57 \\
Snakes & 19 & 12.02 \\
Darkness & 9 & 5.70 \\
Sudden sounds & 3 & 1.90 \\
Unknown people & 2 & 1.26 \\
Get lost & 3 & 1.90 \\
Don't know & 4 & 2.53 \\
Overall & 158 & 99.99 \\
\hline
\end{tabular}

It is interesting that students that want to go on a summer camp also have some fears regarding camping. Analyzing the values shown in Table 3, where students could give multiple answers regarding their fears, it is evident that the largest number of students 
(45.57\%), in this sample, are afraid of wild animals (bears, wolves, etc.), while $29,11 \%$ of them are scared of spiders and bugs. A somewhat smaller number of them cited snakes $(12.02 \%)$, as the cause of their fears, while only $5.7 \%$ wrote that they would be afraid of the dark. Other mentioned fears were presented a very small percent (Table 3).

Children's attitudes about knowledge and behavior towards animals seem to be influenced by sociodemographic characteristics such as age, ethnic backgrounds, sex, area of residence, scholastic ability, socioeconomic status, parental occupation, knowledge of the natural world, active participation in nature-oriented activities, and a variety of cultural agents including books, television, school, family and friends (Kellert \& Westervelt, 1984).

Spiders are traditionally considered to be among the least popular animals. Current evidence suggests that a negative attitude towards spiders could be influenced by both cultural and evolutionary pressures. Some researchers suggest that science education activities could positively influence students' perceptions of spiders (Prokop, Tolarovičová, Camerik, \& Peterková, 2010).

From small number of students who would not go camping, $26.31 \%$ of them think that they are too small for that, $21.05 \%$ of them stated that they will be bored, while the same number of them, $21.05 \%$, wrote that they do not like camping. $10.53 \%$ cited bugs, the same percent cited insects as a reason for disliking camping, while $1.53 \%$ had no explanation for their attitude.

All these fears could be eradicated by familiarizing students with details about the organization of camping, about the specific location where they would be stationed in the camp (to emphasize that they are going to an organized camp, which was previously cleared, where the grass is mown and where the process of disinsection and deratisation have been carried out). Program development, including needs, staff qualifications, criteria for clients, individual treatment planning, trip planning, staffing patterns, menus, assessment, conducting therapy, funding, and marketing must be done on a professional level (Davis-Berman \& Berman, 1994) due to overcoming suspicious parents and children attitudes. Attention should be paid on the fact that students are from urban areas, which imposes the assumption that most of them are not met with insects and animals in their natural environment, so those fears could be declared somewhat unfounded. For this reason, camping would be a real opportunity for students to be liberated from their fears of facing nature.

Table 4 A comparison of recorded fears for students with different experiences from summer camp (Bondžić, 2012).

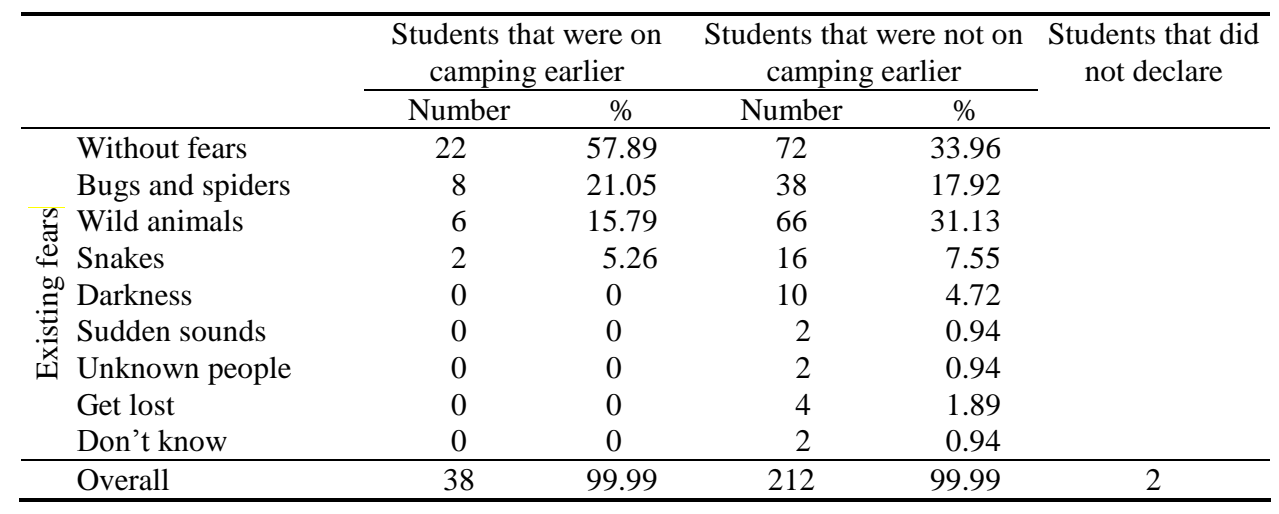


The analysis of the answers was done to check the differences between students' attitudes regarding camping and the facts that they never been there earlier (Table 4).

Also, the mentioned data show an attempt to research the dependence of student fears, regarding their previous experience with camping. The most interesting thing is that almost two thirds of the students that had been camping at least once (57.89\%) answered that there is nothing to be afraid of there. On the other hand, of students that have never been camping only one third $(33.96 \%)$ were not afraid to go there. Most stated fear of wild animals (31.13\%), then fear of bugs and spiders $17.92 \%)$, and thirdly fear of snakes (7.55\%). Fear of darkness is present in $4.72 \%$ of students that had not been camping, but in the group of experienced campers there is no such fear. A smaller number of inexperienced students will be afraid of sudden sounds, unknown people, and getting lost, while there is no such fears in the experienced group.

\section{DISCUSSION}

The obtained results may indicate that students' fears exist in part due to a lack of experience camping, and some of them could easily be overcome by going camping.

In a study of 6th-grade students, it was determined that ecologistic and moralistic attitudes toward the environment correlated even with talking about the environment at home, watching nature, and reading about the environment. On the contrary, regarding our research, a week-long Sunship Earth program at a residential camp did not produce any measurable differences in ecologistic or moralistic attitudes. The results suggest that the students entered the camp program with moderate levels of these attitudes, derived from several influences, including family, media, and previous school-based environmental education programs (Eagles \& Demare 1999).

Close to $90 \%$ of 145 children ages 12 to 14 reported that they spent time in class discussing wildlife, which influences the formation of the most prevalent humanistic, moralistic, naturalistic, and ecologist attitudes respectively (Eagles \& Muffitt, 1990). The assumption is that realistic wilderness experience is needed regarding taking a stand about camping and could have a stronger impact than just discussing it.

Many large companies organize camping activities, regardless of their employee's attitudes, not just as a therapeutic measure but also through leadership programs, and programs for executives or college students (Davis-Berman \& Berman, 1994).

Beside ordinary young people, delinquent populations, young people with health problems or disabilities also benefit from staying in nature (Davis-Berman \& Berman, 1994). A proposition based on these bases could be defined as an attitude that sometimes young people must be taken to the wilderness, regardless of their negative attitude.

Early youth experiences in camping could have a strong influence on later family decision making regarding tourism behavior and attitudes. Previous experience must be explored as a factor in all three modes of making decisions (Nichols \& Snepenger, 1988) husband-dominant, wife-dominant and joint decision making by the husband and wife.

Positive effects of staying in nature are reflected through health-sanitary, psycho-social, sport-recreational and pedagogic educational importance (Miletić, 2011). Previous research (Gillet, Thomas, Skok, \& McLaughlin, 1991) indicated that changes in self-concept, selfesteem and knowledge about the environment can occur from short-term wilderness 
experiences. In the actual study 6 days in nature led to a significant increase in the experimental group in 6 of 16 different measures. This research shows that students have a positive attitude regarding camping, and that they have a desire to spend time in nature.

A small number of students do not want to attend these kinds of classes. Among them, the opinion that they are not mature enough prevails, they do not like that activity, some believe that they will be bored during camping, and a small number experience inconvenience when it comes to insects. Students' negative attitudes, whose causes are mentioned before, could easily be changed with previous theoretical preparation, and through organizing short-term stays in nature, such as a half-day and one-day trips and excursions, with an emphasis on children's exposure to the natural environment.

Most projected fears on possible stays in a camp are wild animals, bugs and spiders, snakes, darkness, sudden voices, getting lost and unknown people.

All of the mentioned fears regardless of type have been integrated by the fear of the unknown, so one form of solution is recommended, and it is dealing and confrontation with these "inconveniences" and fears, where this procedure leads to gradual neutralization and disappearance of fears through the psychological principle of desensitization. (Knežević, 2015; Miletić, 2016). This fact is confirmed by the results of this study where $65 \%$ of children with previous experience of staying in nature showed a complete absence of any fear. In this case camping represents a tool, and a close relationship with nature represents the main goal.

The offered activities can become a significant interest in a certain number of children, which often turns into professional orientation in the later stages of their engagement in mountaineering, alpinism, speleology, skiing, guide services, rescue services and armed forces (Mijatović, 2002).

It is desirable that school sport activities be a part of the educational process. Sport is of multi-dimensional importance and should be studied from several aspects (Savić, Stojanović, Ranđelović, \& Stojiljković, 2015). Although there are legal regulations (plans and programs) and recommendations for organizing all forms of teaching in nature within the educational process of teaching physical and health education in elementary and high schools, there are obstacles in this segment of the organization such as: an insufficient number of planned activities (cross, trips, summer holidays, wintering, campfire, etc.), a small number of physical education teachers who want to organize these activities, undefined locations close to the school suitable for the realization of these programs and material problems (the inability to possess technical equipment for their realization) (Farkaš, 2005). Another very important issue regarding experienced students and their attitudes towards camping are contents and activities which are practiced during camping (Jotov, 2013). From the collected and processed data it can be seen that camping as a form of extracurricular educational activity for children of the third and fourth grade has a perspective, and that organization of summer camps in the future is worth the effort.

As 38 students with negative attitudes towards staying in nature make up $15 \%$ of the total tested sample, so the proportion can be reached by the total number of students who do not want to stay in nature. According to official data from the Statistical Office of the Republic of Serbia, for the 2016/17 schoolyear in Belgrade, the third and fourth grade of elementary school is attended by exactly 31.041 students, while in Serbia this number reaches exactly 132.811 students (SORS, 2017). 
The findings of the study are of significance in order to prevent the 38 students of the representative sample of two Belgrade primary schools with a negative attitude towards the examined phenomenon to grow into 4.656 children in Belgrade, i.e., 19.922 third and fourth grade students in Serbia.

\section{CONCLUSION}

From the aforementioned, the importance of staying in nature, active leisure time, the importance of socializing and feeling of belonging, which are of key importance for socialization, as well as the development of responsibility, it can be concluded that camping should to be maintained in schools as an out-of-school teaching activity, especially in schools located in urban areas.

The psycho-social importance of staying in nature is mostly reflected in adapting the man to the conditions such as absence of comfort, where people return to their primary motives and turn to each other.

\section{REFERENCES}

Beyer, K., Bizyb, J., Szabo, A., Heller, B., Kistner, A., Shawgo, et al. (2015). Development and validation of the attitudes toward outdoor play scales for children. Social Science \& Medicine, 133, 253-260.

Bondžić, J. (2012). Logorovanje kao oblik vannastavne aktivnosti učenika trećeg i četvrtog razreda osnovne škole (Camping as a form of extracurricular activities of students of the third and fourth grade of elementary school). Master thesis. Belgrade: Teacher Education Faculty. In Serbian.

Dabović, M., Dobrijević, S., Miletić, K., Višnjić, D., \& Miletić, V. (2009). Ocena značaja i organizacije praktične nastave logorovanja od strane studenata Fakulteta sporta i fizičkog vaspitanja u Beogradu (Evaluation of the importance and organization of practical classes of camping by students of the Faculty of Sport and Physical Education in Belgrade), Fizička kultura, 63(1), 102-108. In Serbian.

Davis-Berman, J., \& Berman, S.D. (1994). Wilderness therapy. Foundations, theory and research. Kendall Hunt Publishing Co, Dubuque.

Hollender, W.J. (1977). Motivational dimensions of the camping experience. Journal of Leisure Research, 9 (2), 133-141.

Gillett, P.D., Thomas, P.G., Skok, L.R., \& McLaughin, F.T. (1991). The effects of wilderness camping and hiking on the self-concept and the environmental attitudes and knowledge of twelfth graders. The Journal of Environmental Education, 22 (3), 34-44.

Grujić, N., Barak, O., Drapšin, M., Karaba Jakovljević, D., Klašnja, A., Lukač, D., Baćanović, M., Brkić, P., Vasić, G., Drenjančević, I., Ibročić, P., Jakovljević, Đ., Mitrović, D., Ponorac, N., Radoš, B., Rajković, Ž., Ćeranić, S. (2017): Fiziologija Sporta (Physiology of Sport). Univerzitet u Novom Sadu, Medicinski fakultet, Novi Sad. In Serbian.

Eagles, F.J.P., \& Muffitt, S. (1990). An analysis of children's attitudes toward animals. The Journal of Environmental Education, 21(3), 41-44.

Eagles, F.J.P., \& Demare, R. (1999). Factors influencing children's environmental attitudes. The Journal of Environmental Education, 30(4), 34-37.

Ewert, A., Place, G., \& Sibthorp, J. (2005). Early-life outdoor experiences and an individual's environmental attitudes. Leisure Sciences, 27 (3), 225-239.

Farkaš, V. (2005). Aktuelno stanje nekih aktivnosti u prirodi u OŠ "Nada Popović” u Kruševcu sa predlogom mera za poboljšanje (Current situation of some activities in nature in elementary school "Nada Popović" in Kruševac with proposal of measures for improvement). Unpublished Thesis, Faculty of Sport and Physical Education, University of Belgrade, Belgrade. In Serbian

Jotov, N. (2013). Bele i zelene škole, metodski priručnik za organizatore nastave u prirodi (White and green schools, methodical manual for organizer of outdoors activities). Association Sport for All, Belgrade. In Serbian.

Kellert, R.S., \& Westervelt, O.M. (1984). Children's attitudes, knowledge and behaviors toward animals. Children's Environments Quarterly, 1 (3), 8-11.

Knežević, R. (2015). Izveštaj sa kampa Džanići 2015 (Report from camp Dzanici 2015). Povratak prirodi, 2-3, 19. In Serbian 
Lazarević, D., Orlić, A., Lazarević, B., \& Radisavljević-Janić, S. (2015). Stavovi učenika ranog adolescentnog uzrasta prema fizičkom vaspitanju (Attitudes of students of early adolescent age to physical education). Fizička kultura, 69 (2), 88-98. In Serbian

Li, Q. (2010). Effect of forest bathing trips on human immune function. Environmental Health and Preventive Medicine, 15(1). 9-17.

Martinović, D., Branković, D., \& Pelemiš, V. (2013). Stavovi roditelja prema aktivnostima u prirodi. (Parents attitudes towards outdoor activities). Sport Mont, 37, 38, 39, 308-315. In Serbian

Mijatović, A. (2002). Uloga pedagoga fizičke kulture u prostorima delovanja planinarske organizacije (The role of a physical culture professor in mountaneering organization). Unpublished Thesis, Faculty of Sport and Physical Education, University of Belgrade, Belgrade. In Serbian

Miletić, K. (2016a). Organizovano pešačko kretanje u prirodi (Organized hiking tour in nature). Povratak prirodi, 5, 20-23. In Serbian

Miletić, K. (2016b). Taktika izleta - upravljanje. (Excursion tactic-Managing). Povratak prirodi, 4, 14-16. In Serbian

Miletić, V. (2011). Izlaz, iza otvorenih vrata (Exit, behind an open door). Autonomous Edition of Author, Belgrade. In Serbian

Miletić, V. (2016). Praktikum predmeta Aktivnosti u prirodi (Outdoor activities subject's workbook) Belgrade: Faculty of Sport and Physical Education. In Serbian.

Miletić, V., Rajković, Ž., \& Vidaković, H.M. (2016). Stavovi studenata Fakulteta sporta i fizičkog vaspitanja iz Beograda o uticaju alpinističkih aktivnosti na socijalizaciju grupe i budući rad u struci (Attitudes of students of the Faculty of Sport and Physical Education from Belgrade about alpinism activities influence on group socialization and future professional work). In T. Stojanović (Ed.). 3rd International Conference Anthropological and Theo-Anthropological Views on Physical Activity from the Time of Constantine the Great to Modern Times. Kopaonik, Serbia, March, 23-27, 2016, Book of abstracts (pp. 20-21). In Serbian.

Miletić, V., Rajković, Ž., Mitrović, D. (2018): Obale akvatorije Srbije, (ne)iskorišćeni kilometri za realizaciju nautičkog kampovanja (Coasts of the Aquatorium of Serbia, (Un) Used Kilometers for the Realization of Nautical Camping), book of abstracts, 1. International nautical scientific conference Voden 2017. Univerzitet u Beogradu, Fakultet sporta i fizičkog vaspitanja, p 36. In Serbian.

Murchison, C. (1935). Attitudes, in Handbook of Social Psychology. Worcester, MA: Clark University Press.

Nichols, M.C., \& Snepenger, J.D. (1988). Family decision making and tourism behavior and attitudes. Journal of Travel Research, 26 (4), 2-6.

Nikolić, A. (2004). Aktivnosti škole u prirodi i fizičko vaspitanje učenika (Activities of the school in nature and physical education of students). Unpublished Thesis, Faculty of Sport and Physical Education, University of Belgrade, Belgrade. In Serbian

Prokop, P., Tolarovičová, A., Camerik, M.A., \& Peterková, V. (2010). High school students' attitudes towards spiders: A cross-cultural comparison. International Journal of Science Education, 32 (12), 1665-1688.

R-project (2017). Statistical software for data processing, "R". Retrived on 9th November 2017 at the World Wide Web: https://www.r-project.org/about.html

Savić, Z., Stojanović, N., Ranđelović, N., \& Stojiljković, N. (2015). The differences in the attitudes of elementary and high school children on the importance and development of school sport. Facta Universitatis Series Physical Education and Sport, 13, (2), 229-240.

SORS (2017). Statistical Office of the Republic of Serbia (SORS) for school year 2016/17. Retrived on 15 th October 2017 at the World Wide Web: www.stat.gov.rs

Višnjić, D., Jovanović, A., Miletić, K. (2004). Teorija i metodika fizičkog vaspitanja (Theory and Methods of Physical Education). Faculty of Sport and Physical Education, University of Belgrade, Belgrade. In Serbian

Vučković, G., \& Dopsaj, M. (2011). Stavovi studenata kriminalističko-policijske akademije o nastavi specijalnog fizičkog obrazovanja (Attitudes of students of the Criminal Police Academy on the teaching of special physical education), Fizička kultura, 65 (2), 33-41. In Serbian

\section{UZROCI NEGATIVNIH STAVOVA UČENIKA MLAĐIH RAZREDA OSNOVNIH ŠKOLA PREMA KAMPOVANJU}

Organizacija kampovanja kao obavezne aktivnosti za osnovne i srednje škole je data kao mogućnost u obrazovnom sistemu Republike Srbije. Preduslov za realizaciju ovog plana regulisanog zakonima, pretpostavlja pozitivne stavove oba roditelja i učenika. Zbog njihove prirode, stavovi utiču na ljudske mentalne funkcije. Uzorak $u$ ovoj studiji sastojao se od 252 učenika tréceg i četvrtog razreda, iz po pet odeljenja dve osnovne škole iz Beograda. Kao instrument istraživanja korišćen je upitnik, sa glavnim ciljem da evidentira broj učenika sa negativnim stavom prema kampovanju, $i$ da se objasne motivi za ovakve stavove. Rezultati su pokazali da 15,07\% ispitanika ne želi da ide na 
kampovanje. Neki misle da nisu dovoljno zreli, ne vole pomenutu aktivnost i misle da će njihov kamp biti dosadan, a nekima smetaju insekti. Najčešći projektovan strah od mogućeg smeštaja u kampu su strahovi usmereni ka divljim životinjama, bubama, paukovima, zmijama, mraku, iznenadnim zvucima, gubitku i nepoznatim ljudima. Zajedničko za sve pomenute strahove bez obzira na njihov tip je strah od nepoznatog. Kao rešenje za ovaj problem, preporučuje se suočavanje sa neprijatnostima koje strahovi donose, gde dolazi do postepene neutralizacije i njihovog nestanka. Zaključak je da se svi ovi strahovi mogu iskoreniti upoznajući učenike sa detaljima oko organizacije kampa i njegovoj lokaciji. To potvrđuju i rezultati upitnika, u kome postoje veći broj strahova među učenicima koji nisu boravili u prirodi. Pozitivni efekti boravka u prirodi mogu se videti kroz zdravstveno-higijenski, psihosocijalni, sportsko-rekreativni i edukativni značaj. Psiho-socijalni značaj se uglavnom ogleda u prilagođavanju čoveka na uslove odsustva komfora gde se ljudi vraćaju svojim primarnim motivima $i$ okreću jedni drugima.

Ključne reči: nastava, strahovi, povratak prirodi 